Litinfinite Journal

ISSN: 2582-0400 [Online]

CODEN: LITIBR

Vol-1, Issue-1 ( $2^{\text {nd }}$ July, 2019)

Page No: 23-33

DOI: 10.47365/litinfinite.1.1.2019.23-33

Section: Article

\title{
Pop Music, Literature and Gender: Perceptions of Womanhood in Grande's “God Is a Woman” and Achebe's Things Fall Apart
}

\author{
Chidimma Nwabueze \\ Post-Graduate - English and Literary Studies - University of Nigeria, Nsukka
}

\begin{abstract}
Pop music has become a platform where discourses of gender are analyzed and challenged. Ariana Grande's "God Is a Woman" joins the ongoing conversation to challenge the status quo by creating a narrative that showcases the supremacy and importance of the woman in the society. However, this narrative has been in place in the pre-colonial Igbo society where the woman occupies significant positions and status in the society. This society recognizes the supremacy of the woman and an appropriate reverence is given to her. This study suggests that the concept behind the song and its video is in close resemblance with the way the precolonial Igbo society views women by examining the status of women in the society represented in Things Fall Apart. Even though the novel shows strains of the patriarchal society, it has not failed to showcase the important status of the woman as recognized by the precolonial Igbo society. This paper does so by conducting an interpretive and explicative analysis of the novel and highlighting how it is in tandem with the feminist ideology that is propagated in the music video. This research is an attempt to demonstrate how the feminist agenda propagated in "God Is a Woman" resonates with the important roles of women in Things Fall Apart both socio-politically, religiously and economically.
\end{abstract}

Keywords: Womanhood, Precolonial Igbo society, Pop Music, Feminism, Womanism

Pop music serves as a means whereby some aspects of gender identity are questioned, analyzed and even replaced. It aligns with feminism in trying to fight against marginalization, push for equal rights and elevate the woman. One of such attempts can be seen in Ariana Grande's "God Is a Woman" which can be said to be a rebellion against the idea of the gender of the Christian God and the elevation of the place of the woman in the society. This resonates in many instances with the perception of the woman in the Precolonial Igbo society. A lot of arguments have been raised for and against the relevance of feminism in Africa and whether the title is suitable for the experience of women in Africa leading to the emergence of different strains of feminism like Womanism and Stiwanism that portray the unique African women struggle. The emergence of Womanism is an African women approach to feminism which suggests that the experience of women in Africa is different from the experience of women in the western world from which feminism has emerged. So many cultures and attributes exist in the precolonial era that reveres women of which the focus will be on the Igbo tribe, a tribe in West Africa, Nigeria. It is against this backdrop that this paper wishes to examine womanhood in precolonial Igbo society as represented in 
Litinfinite Journal

ISSN: 2582-0400 [Online]

CODEN: LITIBR

Vol-1, Issue-1 ( $2^{\text {nd }}$ July, 2019)

Page No: 23-33

DOI: 10.47365/litinfinite.1.1.2019.23-33

Section: Article

Things Fall Apart by Chinua Achebe and its resonance with the feminist agenda that is pushed in "God Is a Woman" by Ariana Grande. Many people have argued that Achebe's novel is a reflection of the patriarchal society of the precolonial Igbo. This paper however, does not deny that there are various aspects of the patriarchal society that marginalizes women in the novel, but it presents the complex representation of the role of women in Achebe's novel and how it has aligned with Ariana Grande's "God is a woman." It appears that the song rebels against the notion that makes it a taboo to imagine women in positions which society ordinarily puts the "normative Masculine gender" but some of these roles are already seen as the right place for the woman in the novel as Womanhood in Precolonial Igbo society is revered and seen as sacred in various aspects. This paper argues that the precolonial Igbo as represented in Things Fall Apart aligns with the imagery of the elevated status of the feminine gender in "God Is a Woman" through the religious, socio-political and economic power of the woman during the era.

\section{Womanhood in "God Is a Woman" and Things Fall Apart: A Comparative Approach}

Some tenets guiding the western view of feminism which includes elevating the status of the woman has been in place in the Igbo society before the coming of the colonial masters and this is reflected in Things Fall Apart. Not denying the fact that there are aspects of the culture in precolonial Igbo society that need to be changed but there are some positions given to the Igbo woman in society that has been corrupted after the contact with the colonial master which has also adulterated the culture of the Igbo. Ikechukwu Orjinta has noted that:

African women might not have been equal to men in the sense of gender equality. One would instead insist that the African culture, prior to the advent of European culture had in place a status for women which fitted suitably into the concept of gender complementarity. This means that the African woman had naturally equally important participation and roles to play in the society as her male counterpart. Gender complementarity is what one has discovered in the raw African cultural milieu before the corruption of European Christianity and Arabian $\operatorname{Islam}(284)$

What this simply means is that even though we cannot entirely deny the chauvinistic nature of the Igbo society during the precolonial era, one cannot ignore the high value in which the culture places the woman as compared to the culture of the colonial masters as reflected in Things Fall Apart. Puwarno Puwarno posits that:

At first glance, the role of women in Chinua Achebe's "Things Fall Apart" may appear to be unfairly limited in terms of their authority and power. People have not paid much attention to it beyond going along with the assumption that this novel presents women as a sadly oppressed group with no power. This assumption may appear to be right, but upon delving beneath this deceiving surface, one can see that the women of the clan hold some very powerful positions (1) 
Litinfinite Journal

ISSN: 2582-0400 [Online]

CODEN: LITIBR

Vol-1, Issue-1 (2 $\left.2^{\text {nd }} J u l y, 2019\right)$

Page No: 23-33

DOI: 10.47365/litinfinite.1.1.2019.23-33

Section: Article

These powerful positions noted by Puwarno is what the character of Grande is pushing for as reflected in the song, "God Is a Woman" where the woman can occupy any position including the supreme position of the almighty. The music video has also gone ahead to underscore this point. Alison Stone notes that "music video should be analyzed in terms of how they can assert or dissert a song's meaning, which can potentially alter the original track's message" (30). The music video of this song serves as an upgrade to the lyrics through its use of symbols, dimagery, themes and characters that challenge gender roles, fights misogyny and marginalization. In fact, it can be concluded that the music video carries a heavier import than the lyrics of the song itself. "God Is a Woman" is a song that has undertaken the task of reordering epistemologies by analyzing the obstacles that women face in society which stops them from realizing their full potentials and conducting a reversal while at it. Pop music has been a means where people express their opinion on gender, sexuality or racism. Carl Emery has seen this relation as she notes that "gender identities, like other identities, are something we continually reshape and re-imagine in the course of our lives. Popular music offers a set of spaces in which this re-imagining can take place"(1). In the first stanza of the song, the main character, Grande, stands on the globe which symbolizes the world and a cloud-like circular ring rotates round her waist while singing:

You, you love it how I move you

You love it how I touch you

My one, when all is said and done

You'll believe God is a woman (Line 1-4)

The interpretation that can be deduced from the imagery here is that of a situation where a woman occupies an apex position in the world where she is able to rule her world and make positive changes. The symbol of the cloud-like ring round her waist lay credence to the latter. This goes to show that a woman can turn any opportunity to a gold mine as the song notes "you love it how I move you/.../when all is said and done/you'll believe God is a woman"(Lines 1-4). This means that after the woman gives the world her Midas touch, everyone will believe in her powers and abilities to change the world. This is in line with the famous quote of Archimedes of Syracuse where he states, "Give me a place to stand and I shall move the earth." On this, Alexis Rhiannon posits that:

The underlying theme throughout the "God Is a Woman" video is the strength of womanhood, which Grande highlights in the video's first moments. As she gyrates in the middle of the Milky Way, it suggests that feminine energy is at the center of everything, a message that becomes a constant throughout the video" 
CODEN: LITIBR

Vol-1, Issue-1 ( $\left.2^{\text {nd }} J u l y, 2019\right)$

Page No: 23-33

DOI: 10.47365/litinfinite.1.1.2019.23-33

Section: Article

The song goes further to state: "And I, I feel it after midnight/A feeling that you can't fight/My one, it lingers when we're done/You'll believe God is a woman"(Stanza 1, Lines 58). This line is referring to the men in the society of the persona, telling them that their tools of oppression have been rendered powerless and they cannot fight back to take the power away from the woman. In the second stanza, the song however seems to renegade and assume that the men might still want to organize an uprising but she doesn't mind because she has everything in place already. The lines go thus; "I don't wanna waste no time.../You ain't got a one track mind.../Have it anyway you like/ And I can tell that you know how I want it"(Lines 1-4). This stanza shows that the woman doesn't want to waste much time to effect the change despite the fact that she knows the man might still want to fight back so as to regain his control over her but she doesn't really care as she notes in Line 3, "Have it any way you like.", because It wouldn't still stop her from achieving her goals. She continues: "And I can tell that you know how I want it" (Line 5). This line suggests that no other gender can relate to wielding this power except for this "normative gender" who is afraid that the table might turn against him. The line is accompanied by the imagery of two men in a foamylike bed dancing and wriggling as if they are struggling to get up as the woman lies on top of a stool that represents an elevated status higher than theirs. They wriggle around, unable to get up from their "trance".

Alternatively, the Igbo society in Things Fall Apart already has such a position in place for the woman where she wields a socio-political and judicial power. She does not need to fight to get such powers from the man because she already has her own recognized positions. Women in the novel act as law enforcement agents in some cases that have to deal with keeping order in the community and making sure that there are no defaulters. Such can be seen in the scene during the marriage of Obierika's daughter and the women in the villages go to join in the cooking as is the custom. Suddenly, a commotion is heard and it appears that someone's cow has been let loose and it goes to destroy another person's farm. The women all rush out to drag it back to the owner after which they collect the penalty for such offence from the owner. According to Mba Nina Emma:

African women were solidly involved in leadership roles in the pre-Christian era. Sometimes women's socio-political and judicial roles were complementary to those of men and at times they were independent. As far as equality was concerned women were not equal to the men in the societies under study but there was no doubt that their status was much higher compared to what obtained with Islam, Christianity and colonialism (qtd.in Orjinta 277).

In addition, the existence of Umuada although mentioned once in the novel, also lays credence to the socio-political power of women. This group wields more power than the Umunna that the marriage of Uchendu's daughter wouldn't have gone further without their presence. That is why their presence is specially recognized in the build -up of the 
Litinfinite Journal

ISSN: 2582-0400 [Online]

CODEN: LITIBR

Vol-1, Issue-1 ( $2^{\text {nd }}$ July, 2019)

Page No: 23-33

DOI: 10.47365/litinfinite.1.1.2019.23-33

Section: Article

celebration. Till this day, the Umuada is recognized and respected in Igbo land as agents of peace and change.

Further, it is quite difficult to get someone that has tasted power to relinquish it because it is the most difficult thing to do after enjoying the privileges that come with it. Grande admires the fact that this so-called normative gender is not afraid to fight so as to stop this from happening by grabbing back their stronghold. As she notes: "Boy,I like that you ain't afraid( Line 6). However, before the men are able to rise up from the obstacle to get back the power, the deed is done already as the woman has already garnered a stronghold. They get frustrated as they haul different labels and names at her. This is represented by the imagery of Lilliputian men standing atop an open book that looks like the Christian bible and picking all negative labels from the book and throwing them at her. Such words include derogatory words used to put women down and make them think they are not good enough especially when they are in leadership positions, where a confident and principled woman that refuses to bend for anyone is seen as aggressive and arrogant. Words like "bitch, fake, dumb, hoe". These words are slut shaming words that are used by the men to describe women as less intelligent and inferior beings. The video has helped to showcase this message. Just like Carl Emery argues:

It is not only features of musical style that can contribute to articulating gender identities - so can record cover art, fashion and performance styles, music videos, and dance routines. These various elements are not straightforwardly 'external' to what we might think of as 'the music itself'. Rather, these surrounding elements do much to shape how songs are received and understood, how we locate them in terms of genre, and what gendered meanings we hear in them (Emery, 3).

She however doesn't react to such vitriol, instead, she takes the moral high ground and doesn't do anything as she is already above the world and fighting them would be to roll in the mud with pigs. Her lack of reaction also goes to show that if more women were leaders in the world, perhaps there will be no wars. However, she continues with pushing her agenda by keeping her stance and noting that: "I'm telling you the way I like it, how I want it"(stanza 2 line 8). This shows that she is sending a message that no matter what they do, she cannot be discouraged.

Contrastively, in Things Fall Apart, not minding that Okonkwo's beating of his wife is condoned and he only gets punished because it happened in the week of peace, the complexity of this society shows that in Precolonial Igbo society, a man that fights with a woman is regarded as a coward because biologically, most men are stronger than women. In the scene of the settling of the dispute between Uzowulu and his in-laws because he beats his wife, Evil Forest, one of the masquerades notes that a man fighting a woman is not bravery. 
Litinfinite Journal

ISSN: 2582-0400 [Online]

CODEN: LITIBR

Vol-1, Issue-1 ( $2^{\text {nd }}$ July, 2019)

Page No: 23-33

DOI: 10.47365/litinfinite.1.1.2019.23-33

Section: Article

Thus he tells the man, "Go to your In-laws with a pot of wine and beg your wife to return to you. It is not bravery when a man fights with a woman" (75).

Again, "God Is a Woman" goes further to show the fight by women against agents of oppressors that is stopping them from being what they want to be. The image shows women of all color and race represented by different hair color made up of Brunette, Blonde, and black hair all standing in harmony with the character of Grande. This part is accompanied by the chorus as the character sings: "And I can be all the things you told me not to be/When you try to come for me, I keep on flourishing" (Lines 1-2). These lines try to counteract the stereotypes given to women in society that make them feel they are less intelligent and inferior to achieve their dreams as she notes that she can be all the things they have said she cannot be no matter the obstacles they place in her way.

On the Other hand, the precolonial Igbo society believes that some positions have been destined by the gods for the woman to occupy and one of these is the position of a priestess. Even though it is a religious position, it is also a political one as there is a thin line between religious and political positions at that time. The African Traditional religion practiced by the Igbo is intertwined with the politics at that time. Hence, the respect for priests and priestesses as both religious and political heads. The priestess is given the same respect as the priest. Orjinta notes that, "in A.T.R. if there are priests, there are equally priestesses; where there are prophets, there were prophetesses as well. In this way there was a level of gender balance. Hence, though the status of the African woman may not equal that of the man in A.T.R., she possesses irreplaceable roles as medium, diviner, herbalist and priestess"(242). Thus, the priestess cannot be stopped by any man to occupy this role. In the novel, the Priestess, Chielo is the most respected person after Agbala, the oracle. She is respected and feared even by Okonkwo himself who fears no man or woman. She rebukes Okonkwo when he tries to stop her from taking Ezinma. Nobody, throughout the novel, before the coming of the colonialist, has the power to talk to Okonkwo like that without getting a reaction from him. It is also worthy of note to know that the name of the highest oracle in the land which is Agbala is also a term used to refer to a woman in the novel and this may not be a mere coincidence.

Furthermore, the song and its title has succeeded in raising a conversation concerning the gender of the Christian God who is strictly seen as a white male and no other gender can be thought of to replace that. The male is seen as the essential; hence, the almighty God must be male. Simon de Beauvoir has seen this relation. He states thus:

Humanity is male and man defines woman not in herself but as relative to him; she is not regarded as an autonomous being... she is defined and differentiated with reference to man and not he with reference to her; she is the incidental, the inessential as opposed to the essential. He is the Subject; he is the Absolute-she is the Other (xvi). 
Litinfinite Journal

ISSN: 2582-0400 [Online]

CODEN: LITIBR

Vol-1, Issue-1 ( $2^{\text {nd }}$ July, 2019)

Page No: 23-33

DOI: 10.47365/litinfinite.1.1.2019.23-33

Section: Article

The song however rebels against this status quo. The image of the character of Grande in the wick of the lighted candle that lights the universe represents the quotation in the bible where Jesus says "I am the light of the world..." (John 8:12). She becomes the fire that showers rays of light upon the universe. This is accompanied by the image of this same character sitting on the globe and running her hand all over it while singing: "... believe that God is a woman." It is pertinent at this juncture to note that this is considered by many as blasphemy, as God has already been assumed to be a white male. This is not the only message this line is trying to convey, it is also trying to draw an array of possibilities of what a woman can be.

Similarly, the images seen in the video juxtapose with the idea of the supernatural in the novel. The religion practiced in precolonial Igbo society is polytheistic in nature which believes in the existence of Gods and Goddesses. While the video tries to put forward a narrative that places the gender of God as female, the Igbo society in Things Fall Apart already recognizes a female god which is the Earth goddess who wields the greatest power in the land, a black female as against a white male. Ani, the goddess, is known as the owner of lands and they try to avoid anything that will offend her. The Igbo culture forbids people even till this day to commit actions that are deemed as abominations in order not to incur the wrath of Ani. Therefore, in the novel, they avoid such behaviors and necessary sacrifices are conducted to appease her when such things occur. For instance, when Unoka dies of a swelling stomach and he is taken away to the evil forest so as not to offend the earth goddess. In addition, when Okonkwo violates the week of peace, he makes sacrifices to appease her. It might not be a mere coincidence that one of the greatest men in the land like Okonkwo who is favored by his chi can be befallen by a such a misfortune like manslaughter that leads to his banishment which is a necessary rite that will douse the wrath of Ani and this comes in the heels of Obierika's reservation for his contribution in the death of Ikemefuna .Obierika tells him that his corroboration to kill Ikemefuna may offend the earth goddess as he notes that "Such actions make her to wipe out whole families"(Achebe 53). Okonkwo and his family are not wiped out but they are banished which is close to being wiped out. It is also noteworthy to know that the greatest festival in the land, the new yam festival, is for Ani. As stated in the novel, it is one for "giving thanks to Ani, the earth goddess and the source of all fertility. Ani played a greater part in the life of the people than any other deity. She was the ultimate judge of morality and conduct. And what was more, she was in close communion with the departed fathers of the clan whose bodies had been committed to mother earth" (Achebe 29).

Again, in the song, the supremacy of the woman has been recognized even among the animals as we see in the imagery of rabbit- like animals coming out from the hole and screaming in animal language. This can be deduced to mean a clarion call to the whole world to recognize this new authority. This is accompanied by a split uncountable image of Grande coming out from a place with different plants sprouting out of her body. This shows the 
Litinfinite Journal

ISSN: 2582-0400 [Online]

CODEN: LITIBR

Vol-1, Issue-1 ( $2^{\text {nd }}$ July, 2019)

Page No: 23-33

DOI: 10.47365/litinfinite.1.1.2019.23-33

Section: Article

woman as the source of life without which life cannot flourish. This is accompanied by the lines in stanza 5: "I tell you all the things you should know/so baby, take my hand save your soul/we can make it last, take it slow hmm"(Lines 1-3). This line, although seems to be talking to a particular person, is actually a warning to everyone that is resisting this change to desist from it so that this lasting peace brought about by this harbinger of life can be infinite. The line 6 continues: "And boy, if you confess you might get blessed." This line tries to tell people to confess and recognize the power and supremacy of the woman so as to enjoy the fruits it will yield. This is accompanied by the imagery of a pregnant Grande which further underscores the supremacy of the woman as a mother and a source of life.

Similarly, in Things Fall Apart, the supremacy of the woman as the source of life, fertility and the symbol of life is enacted. A woman is supreme and seen as a protector, Mary Kolawole argues that:

To fully apprehend the place of gender a nd feminism in Africa, a historical analysis is as important as cultural contextualization. The ideal is not to merge all women under an unrealistic canopy of sisterhood, but to recognize and respect specificities, diversities and difference... Gender struggles should not efface other canons of self-definition, but enhance meaningful dynamic womanhood without being ahistorical or acultural. African gender researchers need to transcend the issue of feminism's irrelevance (qtd.in Wale-Olaitan 6)

This society revers the nature of the woman and does everything powerful to protect her and fights anybody that violates her. Thus, when Ogbuefi Ezeugo's wife is murdered by the people of Mbaino, Umuofia threatens to go to war because of her just like Helen of Troy that causes the Trojan War. It is also because of a woman that makes it possible for them to be the most feared by surrounding villages. Thus, we see in the novel:

Umuofia was feared by all its neighbours. It was powerful in war and in magic, and its priests and medicine-men were feared in all the surrounding country. Its most potent war-medicine was as old as the clan itself. Nobody knew how old. But on one point there was a general agreement-the active principle in that medicine had been an old woman with one leg. In fact, the medicine itself was called agadi nwanyi, or old woman. It had its shrine in the centre of Umuofia, in a cleared spot. And if anybody was so foolhardy as to pass by the shrine after dusk, he was sure to see the old woman hopping around (Achebe10).

This can also be seen as one of the reasons for their reverence of women in the novel. This is also recognized in the idea surrounding the name "Nneka" which means Mother is supreme. A woman is seen as the harbinger of refuge and hope. The men here as patriarchal as they may seem cannot deny this great role and position the woman occupies in their society seeing their importance. As Okonkwo goes into exile in his motherland, the Uncle Uchendu tells him: 
CODEN: LITIBR

Vol-1, Issue-1 ( $2^{\text {nd }}$ July, 2019)

Page No: 23-33

DOI: 10.47365/litinfinite.1.1.2019.23-33

Section: Article

Why is it that one of the commonest names we give our children is Nneka, or 'mother is supreme'? We all know that a man is the head of the family and his wives do his bidding. A child belongs to his father and his family and not to his motherland. Any yet we say Nneka...A man belongs to his fatherland when things are good and life is sweet. But when there is sorrow and bitterness he finds refuge in his motherland. Your mother is there to protect you...And that is why we say that mother is supreme (Achebe 106-107).

In contrast, men in the society of "God Is a Woman" don't fully understand this power wielded by the woman as they continue fighting against it as seen in the image where three Lilliputian men continue pushing the character in her belly, this part of the body that is the source of procreation as she kneels over them-unperturbed, unrelenting. The "female God" however comes to judgement, wielding a huge gavel while quoting: "And I will strike down upon thee with great vengeance and furious anger those who attempt to poison and destroy my sisters. And you will know my name is the Lord when I lay my vengeance upon you." This is a modified version of Ezekiel 25:17. It shows the wrath of God against the oppression of women. This God, afterwards, shatters the glass ceiling which obstructs the woman from reaching her goals with the gavel. Rhiannon in "The Meaning of Ariana Grande's "God is a Woman notes that the glass ceiling moment symbolizes the progress made by women in the fight for equality. This moment is accompanied by the scene where the woman opens up her vagina and rays of light comes in from the roof where the glass ceiling is shattered, lighting up the whole place, followed by chants from many women that seem like heavenly choir singing: "God is a woman." This goes to show that the war against gender inequality has been won.

However, the women in Things Fall Apart cannot relate as they have been empowered with certain tools to achieve their goals and this is done through economic empowerment. Whereas the men grow yams, the women grow other kind of crops. We can agree that:

The analysis of women's roles in Nigeria's liberation struggle in the pre-colonial period can be understood from the nature of the economic, social and political actions they were engaged in that period. During the pre-colonial period, Nigerian women participated actively in the private and public spheres and usually have independent access to resources. The exception to this were the women in the Northern part of the country comprising mainly of the Hausa-Fulani whose commercial activities were restricted as a result of the use of the Islamic purdah. Even at this, they still made a strong impression on the socio-political landscape of the region (Abdul, Adeleke, Adeyeye, Babalola, Eyo, Ibrahim, Voke-Ighorodje, Onose 6)

The concept of "housewife" is western. So also is the concept behind Oriaku (a woman that only enjoys the husband's wealth) which is a translation of "Mrs" where the woman only sits around at home and expects the man to be the sole provider. It is never in existence during precolonial era and that's why while the men grow yam, women grow cocoyam, groundnuts and every other crop so as to be able to cater for themselves. They also help their husbands in 
Litinfinite Journal

ISSN: 2582-0400 [Online]

CODEN: LITIBR

Vol-1, Issue-1 ( $2^{\text {nd }}$ July, 2019)

Page No: 23-33

DOI: 10.47365/litinfinite.1.1.2019.23-33

Section: Article

their farms. Hence, we can say that economically, women are empowered in Igbo society and economic empowerment can lead to arrays of powers and other forms of independence. We can conclude that "Culturally speaking curtailing women's economic participation was foreign to most African communities unlike in the same era in Europe where in England, for instance the wife fitted into the legal entity of the husband. She was regarded as a minor, a non-person and could only be economically and socially custodied by a male"(Uchendu qtd.in Orjinta 282). In pre-colonial Igbo society, preventing women from growing yam does not come from a place of marginalization; rather, it comes from a place of care where yam is seen as a difficult crop to grow and since biologically, they are not as strong as the man, they revert to growing other crops like cocoyam. An Igbo myth tries to proffer an explanation on the origin of yam and cocoyam as male and female crop respectively. According to this myth:

When Eri died, the food supply (from heaven) ceased and Ndri at Aguleri complained to chukwu that there was no food... and Chukwu told him, he was to kill and sacrifice his eldest son and daughter... This killing of eldest son and daughter was carried out and the bodies buried in separate graves. Three native weeks later, shoots appeared out of the graves of these children. From the grave of his son Ndri dug up a yam... the next day Ndri dug up kokoyam from his daughter's grave... for this reason the yam is called the son of Ndri and kokoyam the daughter of Ndri ( Jeffreys qtd.in Chukwu 39)

There are several attempts by the Womanists to restore the dignity bestowed to African women of pre-colonial times, a dignity that is portrayed in Things Fall Apart which "God Is a Woman" by Grande is propagating - a position that comes naturally to the Igbo woman in precolonial times and has been in place before the culture contact from the Western world. There are, however, undeniable facts about the patriarchal society where the woman is marginalized but certain dignities and powers are bestowed on the woman which resonates with the subject matter of "God Is a Woman" and works pari-passu with the socio-political, religious and economic power of the precolonial Igbo woman.

\section{Work cited}

i. A., Eyo,E., Ibrahim,M., Voke-Ighorodje,M., Onose, M., "Analysis of the History, Organizations and Challenges of Feminism in Nigeria." Nawey, October 2011. www.nawey.net>Feminism -in-Nigeria.

ii. Achebe, Chinua. Things Fall Apart. AWS,1962

iii. Chukwu, Joseph. " Role of Women in the Growth of the Traditional Igbo Economy. "Journal of Culture,society and Development, Vol.10,2015,pp.38-46.www.iiste.org/viewfile/24790/

iv. De Beauvoir, Simone. The Second Sex. Jonathan Cape, 2009. 
Litinfinite Journal

ISSN: 2582-0400 [Online]

CODEN: LITIBR

Vol-1, Issue-1 ( $2^{\text {nd }}$ July, 2019)

Page No: 23-33

DOI: 10.47365/litinfinite.1.1.2019.23-33

Section: Article

v. Emery

,Carl.“Feminism, www.academia.edu/35070317

Gender

and

Popular

Music."

Academia.

vi. Grande, Ariana. God Is m. youtube.com/watch?v=Cf6Cr6Nve7

vii. Orjinta, Ikechukwu. Womanism as a Method of Literary Text Interpretation: A Study of Emergent Women's Images under Religious Structures in Selected Works of Heinrich Böll. Dissertation, University Of Munich, 2013. Edoc.Ub.Uni-Muenchen.De/15969

viii. Puwarno, Puwarno. "The Role of Women In Chinua Achebe's Things Fall Apart." Julisa, vol. 9, No. 1, April 2009, pp. 1-3. www.academia.edu/documents/in/Things Fall Apart.

ix. Rhiannon, Alexis. "The Meaning of Ariana Grande's "God is a Woman" Video." Bustle , July 2018. https://www.bustle.com/p/the-meaning-of-ariana-grandes-god-is-a-woman-video-goesdeeper-than-you-may-think-9759659

x. Stone, Alison. "Girl Power? Examining the Use of Feminism in Pop Music by the Spice Girls and Taylor

xi. Swift.”www.academia.edu/27649110/Feminism_Gender_and_Popular_Music

xii. $\quad$ The Holy Bible, New King James Version. Thomas Nelson,1979.

xiii. Wale- Olaitan, Kemi. "Confronting New Challenges in Feminism in African Literature within the Context of Globalization."Academia, pp.1-11 http://www.academia.edu/28968435/ confronting_new_challenges_in_feminism_in_african_literature_within_the_context_of_glob alization. 